The Historical Journal, 64, 5 (2021), pp. 1311-1331 (C) The Author(s), 2021. Published by Cambridge University Press. This is an Open Access article, distributed under the terms of the Creative Commons Attribution licence (http://creativecommons.org/licenses/by/4.o/), which permits unrestricted re-use, distribution, and reproduction in any medium, provided the original work is properly cited.

doi: $10.1017 /$ Soo 18246 X20000655

\title{
TRUST, FRIENDS, AND INVESTMENT IN LATE VICTORIAN ENGLAND*
}

\author{
JAMES TAYLOR \\ Lancaster University
}

A B ST RACT. Why people trust is a question that has preoccupied scholars across many disciplines. Historical explorations of trust abound, but we know relatively little about the workings of trust in the history of investment. Despite becoming increasingly mediated and institutionalized in the nineteenth century, the market for stocks and shares remained local and embedded in personal relations to a significant extent. This created a complex trust environment in which old and new forms of trust coexisted. Investors sought information from the press, but they also relied upon friends to help them navigate the market. Rather than studying trust in the aggregate, this article argues that focusing on the particular allows us to appreciate trust as an emotional and ultimately imaginative process depending as much on affective stories as rational calculation. To this end, it takes the case of a Bath clergyman and workhouse schools inspector, James Clutterbuck, who solicited investments from a wide network of friends and colleagues in the I880s and I89os. By capturing the complex interplay of friendship, emotions, and narrative in the formation of trust, the article offers a window onto everyday financial life in late Victorian provincial England.

One day in December 1887 , the Reverend Dr James Caspar Clutterbuck called upon his friend and fellow resident of Bath, the Reverend Conolly McCausland, with a business proposition. The chancellor of the exchequer, George Goschen, was reforming local finances, which involved the creation of a local loans stock, backed by the state. Clutterbuck's position as one of her majesty's inspectors of workhouse schools under the local government board gave him privileged access to the investment, the terms of which were attractive. Paying 20 and 15 per cent in the first two years, the stock would revert to a rate of 8 per cent for a further thirteen years. Clutterbuck had invested in the loan himself, but

Department of History, Bowland College, Lancaster University, Lancaster, LA I 4YT, UK james.taylor@ lancaster.ac.uk

* I would like to thank the three anonymous referees whose comments were particularly helpful in improving this article. 
was willing to share the opportunity with his fellow clergyman. A grateful McCausland immediately wrote Clutterbuck a cheque for $£_{5}{ }^{\circ o}{ }^{1}$

Well-connected and well-known locally, Clutterbuck was the ideal person to enlist investors for Goschen's new stock. As a workhouse schools inspector, he travelled extensively throughout the south-west and was therefore able to sign up dozens of subscribers from across the region. His largest investor was another clergyman friend, the Reverend Henry Horatio Pace, who placed a total of $£_{5}, 6_{5}$ o, but Clutterbuck also received sums from smaller investors, such as the school mistresses of the workhouse schools he inspected, several of whom entrusted him with savings of between $£_{20}$ and $£_{100}{ }^{2}$ But by 1891 , a reputation for extravagant expenditure was making Clutterbuck the subject of gossip at the local government board in London. Inquiries were made in Bath, and information was passed to the treasury. ${ }^{3}$ As a result, Clutterbuck was summonsed in October to appear before Bath magistrates charged with obtaining money by false pretences with intent to defraud. The star witness in this state-sponsored prosecution was Chancellor Goschen, dragged all the way from London in order to testify that he had never knowingly met Clutterbuck, and that the reverend's story about a government loan was a complete fabrication. 4

Following five sessions before the Bath magistrates, the case was sent for trial at the crown court, Wells, before Justice Sir Lewis Cave. By now, Clutterbuck, aged fifty-three, had achieved great notoriety: when he was led to the dock dressed in his clerical cloak and collar, he 'was eagerly scanned by a crowded court', and such was the rush to catch a glimpse of him that the public gallery 'distinctly swayed to and fro' and looked like it was about to collapse. 5 Clutterbuck tried to plead guilty to obtaining money by false pretences, but not with intent to defraud. Cave pointed out that he had to plead either guilty or not guilty to the charge as a whole, and after a brief consultation with his solicitor, in a choking voice', he pleaded guilty. ${ }^{6}$ In his summing up, Cave sympathized with Clutterbuck's victims, arguing that the way in which the prisoner had systematically abused 'the trust which they appeared to have reposed in him from the character which he held, as well as upon the friendship which existed between them and himself or members of their families' made this 'one of the very worst cases which in his experience had ever been brought into a court of justice'. He sentenced Clutterbuck to four years' penal servitude.7 Bankruptcy proceedings

\footnotetext{
1 Bristol Mercury, 7 Nov. 1891, p. 3; Western Daily Press, 7 Nov. 1891, p. 3; Bath Chronicle, 12 Nov. 1891 , p. 2.

${ }^{2}$ Bath Chronicle, 12 Nov. 1891 , p. 7; Western Morning News, 30 Nov. 1891 , p. 3.

3 Bath Chronicle, 26 Nov. 1891, p. 7.

4 Liverpool Mercury, 27 Oct. 1891 , p. 5 .

5 Western Daily Press, 23 Nov. 1891, p. 7; Weston Mercury Ẽ Somersetshire Herald, 28 Nov. 1891 , p. 7 .

Clifton Society, 26 Nov. 1891 , p. 9 .

7 Bristol Mercury, 23 Nov. 1891, p. 3; Bath Chronicle, 26 Nov. 1891 , p. 7.
} 
subsequently showed that he had raised approximately $£_{45}$, ooo from at least thirty-seven clients over the course of just under four years. ${ }^{8}$

The episode was utterly mystifying to contemporaries. How Clutterbuck had been able to fool so many of his friends with such an outrageous story was the question that 'every journalist in England' was asking, said The Spectator. 9 The press's preoccupation with the case indicates that the nature of trust and how it worked-and how it failed-were becoming urgent questions by the later nineteenth century. Sociological work suggests that with the growing complexity of modern societies, trust becomes at once more important and less certain: as Anthony Giddens puts it, 'there would be no need to trust anyone whose activities were continually visible, or to trust any system whose workings were wholly known or understood'. ${ }^{10}$ The 'thick' forms of trust based on strong ties that characterize small, close-knit communities are less possible in larger societies with more attenuated relations, where 'thinner' forms of trust in weak ties or impersonal institutions become more common. ${ }^{11}$ Yet, it is clear that in such societies, both forms of trust in fact co-exist, the preference commonly shown 'for transacting with individuals of known reputation' suggesting the persistence of 'thicker' trust. ${ }^{12}$ Indeed, historians of economic relations in modern Britain reject the idea of a linear transition from old to new forms of trust. Margot Finn's work on credit and debt, for example, seeks to complicate the notion that the nineteenth century saw 'the triumph of anonymous consumer relations', highlighting the rich moral economies that continued to structure the market. ${ }^{13}$ Similarly, Aeron Hunt argues that Victorian business saw 'impersonality and abstraction, personalization and embeddedness' co-exist in ways that defy easy categorization. ${ }^{14}$ Older forms of trust were not in opposition to the modern, argues James Vernon. Rather, they were 'attempts to localize and personalize new abstract systems', part of an ongoing 'dialectic of abstraction and reembedding'. ${ }^{15}$

8 Bath Chronicle, 25 Feb. 1892, p. 8. A list of investors was referred to in court but not read; references to it show that it included at least thirty-seven names: Daily News, 9 Nov. 1891 , p. 7 .

9 Spectator, 28 Nov. 1891 , pp. $755^{-6 .}$

10 Anthony Giddens, The consequences of modernity (Cambridge, 1996), p. 33.

11 Bernard Williams, 'Formal structures and social reality', in Diego Gambetta, ed., Trust: making and breaking cooperative relations (New York, NY, 1988), pp. 3-13; Robert D. Putnam, Bowling alone: the collapse and revival of American community (New York, NY, 200o); Dmitry Khodyakov, 'Trust as a process: a three-dimensional approach', Sociology, 41 (2007), pp. $115^{-32}$. For the classic study of weak ties, see Mark Granovetter, 'The strength of weak ties', American Journal of Sociology, 78 (1973), pp. 136o-8o.

12 Mark Granovetter, 'Economic action and social structure: the problem of embeddedness', American Journal of Sociology, 91 (1985), pp. 481-510, at p. 490.

13 Margot C. Finn, The character of credit: personal debt in English culture, I740-I9I4 (Cambridge, 2003), p. 89 .

14 Aeron Hunt, Personal business: character and commerce in Victorian literature and culture (Charlottesville, VA, 2014 ), p. 14.

${ }^{15}$ James Vernon, Distant strangers: how Britain became modern (Berkeley, CA, 2014), p. 15 . 
These insights are particularly relevant when it comes to the market for stocks and shares. A host of factors were seemingly making investment less personal in the nineteenth century. The removal of the trade in stocks and shares from the coffeehouses of Exchange Alley to the London Stock Exchange, the rapid spread of the limited liability joint-stock company funded by hundreds or thousands of shareholders, the growth of national and international investment opportunities, and a mushrooming print culture made up of newspapers, circulars, and advice manuals, were just some of the forces untethering the market from face-to-face relations. ${ }^{16}$ Yet none of this diminished the importance of the human factor: indeed, it placed a greater premium on the personal as investors sought safety in local knowledge and individual assessments of character. ${ }^{17}$ Local markets for stocks and shares were strengthened with the formation of a number of provincial stock exchanges from the $1830{ }^{18}{ }^{18}$ Company promoters wanted local shareholders as they were thought to be the most committed to an enterprise. ${ }^{19}$ Likewise, many shareholders saw investing locally as a way to overcome informational asymmetries and mitigate risk. ${ }^{20}$ And personal networks were particularly important in facilitating women's engagement with the market. ${ }^{21}$ So, despite its growing size and complexity, the financial market was not experienced as anonymous, but was rooted in everyday personal relations.

Exploring the workings of, and interplay between, different forms of trust therefore becomes imperative. If investors still relied on face-to-face contacts for information and advice, how were these personal interactions shaped by the newer, impersonal features of the market, such as growing distance, abstraction, and print? Did old and new forms of trust reinforce or undercut each other? ${ }^{22}$ Though these questions can be approached at the macro level, this

${ }^{16}$ These have been explored in multiple works, including Ranald Michie, The London Stock Exchange: a history (Oxford, 2001); James Taylor, Creating capitalism: joint-stock enterprise in British politics and culture, I80o-I870 (Woodbridge, 2006); Paul Johnson, Making the market: Victorian origins of corporate capitalism (Cambridge, 2010).

${ }_{17}$ Hunt, Personal business, pp. 20-2.

18 W. A. Thomas, The provincial stock exchanges (London, 1973).

${ }^{19}$ Lucy Newton, 'Capital networks in the Sheffield region, 1850-1885', in John F. Wilson and Andrew Popp, eds., Industrial clusters and regional business networks in England, 1750-1970 (London, 2017), pp. 130-54, at p. 134 .

${ }^{20}$ Janette Rutterford, Dimitris P. Sotiropoulos, and Carry Van Lieshout, 'Individual investors and local bias in the UK, 1870-1935', Economic History Review, 70 (2017), pp. 1291-320, at p. 1292.

${ }^{21}$ Janette Rutterford and Josephine Maltby, “"The widow, the clergyman and the reckless”: women investors in England, 1830-1914', Feminist Economics, 12 (2006), pp. 111-38, at pp. $124^{-5}$.

${ }^{22}$ Such questions have been explored in other contexts, including the markets for newspapers, patent medicines, and insurance: Victoria E. M. Gardner, The business of news in England: ${ }_{1760-I 82 O}$ (Houndmills, 2015); Hannah Barker, 'Medical advertising and trust in late Georgian England', Urban History, 36 (2009), pp. 379-98; James Taylor, 'Numbers, character, and trust in early Victorian Britain: the Independent West Middlesex Fire and Life Assurance 
article makes a case for investigating trust more subjectively. Detailed explorations of individual cases of investor behaviour are more typical for the eighteenth century than for the larger nineteenth-century market, and even these do not always probe the question of trust at length. ${ }^{23}$ Consequently, as Matthew Hollow has recently contended, we lack a clear sense of 'how individual investors comprehended and made sense of this potentially confusing world of stocks and shares'. ${ }^{24}$ To address this shortfall, I argue that we can usefully borrow from historians of consumption who have highlighted 'the need to particularize consuming experiences' as the basis for exploring 'the consuming imagination'. ${ }^{25}$ Treating investment not solely as a matter of rational calculation but as a subjective, emotional, and ultimately imaginative process can enrich our understanding of trust in financial markets. ${ }^{26}$ The puzzling case of the Reverend James Clutterbuck and his credulous clients provides the raw material for this investigation into what we could call 'the investing imagination'. Though we do not have access to the private papers of the participants, the court reports published in the press feature detailed evidence about six of his investors, as well as testimony from several other key actors. Alongside the copious accompanying editorials, and subsequent proceedings in bankruptcy, these permit a detailed reconstruction of the episode, which gives a vivid insight into how nineteenth-century investors, particularly provincial investors who were not well connected, understood and experienced the financial market.

Focusing on individual cases can be a compelling way of exploring the cultural practices shaping trusting relations in particular historical periods. ${ }^{27} \mathrm{By}$ bringing into focus attitudes and behaviours that might otherwise be overlooked, such stories can, argues Joan Scott, 'reveal complexities of human experience that challenge the categories with which we are accustomed to

Company fraud', in Tom Crook and Glen O'Hara, eds., Statistics and the public sphere: numbers and the people in modern Britain, c. I80o-20oo (London, 2011), pp. 185-202.

${ }^{23}$ Examples include Anne Laurence, 'Lady Betty Hastings, her half-sisters and the South Sea Bubble: family fortunes and strategies', Women's History Review, ${ }_{15}$ (2006), pp. 533-4o; Koji Yamamoto, 'Beyond rational vs. irrational bubbles: James Brydges the first duke of Chandos during the South Sea Bubble', in Le crisi finanziarie: gestione, implicazioni sociali e conseguenze nell'età preindustriale: selezione di ricerche (Florence, 2016), pp. 327-57.

${ }^{24}$ Matthew Hollow, 'A nation of investors or a procession of fools? Reevaluating the behavior of Britain's shareholding population through the prism of the interwar sharepushing crime wave', Enterprise $\mathcal{E}^{2}$ Society, 20 (2019), pp. 132-58, at p. 133.

${ }^{25}$ Sara Pennell, 'Consumption and consumerism in early modern England', Historical Journal, 42 (1999), pp. 549-64, at p. 56o. See also Helen Berry, 'Polite consumption: shopping in eighteenth-century England', Transactions of the Royal Historical Society, 12 (2002), pp. 375-94, at pp. $37^{6-7}$.

${ }^{26}$ For an analysis of City fiction which makes a similar case, see Jakob Gaardbo Nielsen, 'Poets of promotion: corporate personality and crowd psychology in Guy Thorne and Leo Custance's Sharks (1904)', Journal of Victorian Culture, 26 (2021), pp. 103-18.

${ }^{27}$ Matt Houlbrook, Prince of tricksters: the incredible true story of Netley Lucas, gentleman crook (Chicago, IL, 2016), p. 4 . 
thinking about the world'. ${ }^{28}$ The article does this by unravelling three main strands of the case. The first section demonstrates how Clutterbuck mobilized appearances and reputation to win trust. In particular, it shows how he capitalized on pre-existing relationships with his victims, deliberately embedding financial transactions in the personal and the domestic. This was only part of Clutterbuck's method, so the second section explores how the trust he cultivated also rested on the stories he told his investors. These stories gained both credibility and emotional resonance from their relationship to narratives circulating more widely in late nineteenth-century print culture. This enabled him to sign up risk-averse investors to what were incredibly high-risk investments. With the final section comes a twist which casts Clutterbuck's behaviour in a different light, complicates our notions of victimhood, and brings wider aspects of the market for stocks and shares into view. The aim is to capture the complex interplay of friendship, emotions, and narrative in the formation of trust, providing a window onto everyday financial life in the late Victorian market.

\section{I}

In the deluge of editorials that followed the prosecution, it was repeatedly argued that the case confirmed certain unfortunate but eternal truths about human nature. Clutterbuck's victims fell for his stories because of their gullibility and greed. Though some acknowledged the precarity of those living on interest from investment, most discussions of Clutterbuck's investors were decidedly uncharitable. ${ }^{29}$ Their 'avarice blinds their commonsense, and renders them easy victims to the unscrupulous vagabond who offers them a preposterous return for their money', explained The Bristol Mercury. $3^{\circ}$ Given long-standing habits of imagining women as naïve and credulous investors, some commentators thought it easier to understand how Clutterbuck managed to fool his female victims, though insisting that even they should have been able to consult 'some competent male relative'. ${ }^{31}$ The men, on the other hand, should have had sufficient worldliness 'to brush aside Clutterbuck's romances like a cobweb'. $3^{2}$ Some observers sought an explanation in geography, arguing that the case revealed the extreme naïvety of provincial people. The Daily News observed that the victims exhibited 'the credulity of a herd of

${ }^{28}$ Joan W. Scott, 'Storytelling', History and Theory, 5o (2011), pp. 203-9, at p. 207.

29 Pall Mall Gazette, 23 Nov. 1891 , p. 1.

$3^{\circ}$ Bristol Mercury, 23 Nov. 1891, p. 5. For similar sentiments, see Daily Telegraph, 23 Nov. 1891, p. 5; St James's Gazette, 23 Nov. 1891, p. 4; Star, reprinted in Sunderland Daily Echo, 24 Nov. 1891 , p. 4; Western Morning News, 24 Nov. 1891, p. 4; Shields Daily News, 24 Nov. 1891 , p. 2.

$3^{1}$ Bristol Mercury, 23 Nov. 1891, p. 5. For more on the perceived vulnerability of women investors, see George Robb, 'Women and white-collar crime: debates on gender, fraud and the corporate economy in England and America, 1850-1930', British Journal of Criminology, $4^{6}$ (2006), pp. $105^{8-72 .}$

32 Times, 23 Nov. 1891 , p. 9 . 
rustics at a country fair', while Dundee's Evening Telegraph was more scathing still, concluding that 'moneyed simpletons with an unhealthy craving for an impossibly high rate of interest must be unusually plentiful in Somersetshire and round that way'.33

Quick to emphasize how ignorant Clutterbuck's victims had shown themselves to be about basic elements of finance - that chancellors did not need to borrow at such high rates of interest, and that they did not use schools inspectors as agents - press commentary rarely probed the origins and implications of this ignorance. One of the few newspapers to take the question seriously, The Speaker identified lack of provision for financial education as the root of the problem. It complained that the rudiments of business were rarely taught, and even popular primers on political economy, such as those by Henry and Millicent Garrett Fawcett, did not actually explain the practical dimension of business. This meant that 'the mind of the average educated person is not a blank upon it; it is a kind of nebula'.34 Whereas The Speaker believed that education could combat this problem, The Spectator was perhaps more realistic in regarding such fields of ignorance as an inevitable feature of modern society, with its proliferation of specialized knowledge, where no one could be expert in all things. 'The most intelligent among us are all profoundly ignorant upon some subject or another' - if not money, then astronomy, geography, or medicine - and had no choice but to rely upon others. Whom people decided to trust thus became crucial, and The Spectator was clear about how such decisions were typically made:

It is character which the majority trust, not statements which a large portion of them know they are incompetent to weigh. They think they know a good man from a bad man, and once satisfied that John Smith is good, they are capable of believing on his authority that sunbeams can be extracted from cucumbers. 35

Reading character was therefore the foundation upon which trust was built, the means by which investors navigated the confusing and increasingly complex world of finance.

There is much evidence that Clutterbuck's victims found it reasonable to trust him because of their assessment of his character. He established his trustworthiness through what is best understood as a carefully orchestrated performance, mobilizing appearance, status, and what Matt Houlbrook has called the 'material culture of confidence'. ${ }^{6}$ Indeed, Clutterbuck possessed a special combination of features to inspire confidence. An academic high-achiever, he had

33 Daily News, 23 Nov. 1891 , p. 5; Evening Telegraph, 24 Nov. 1891, p. 2.

34 Speaker, 28 Nov. 1891 , p. 632 . For more on the popular works on political economy by the Fawcetts, see Willie Henderson, 'Millicent Garrett Fawcett's Political economy for beginners: an evaluation', Paedagogica Historica, 40 (2004), pp. 435-53.

35 Spectator, 14 Nov. 1891 , pp. $671-2$. Sunbeams from cucumbers is a reference to Jonathan Swift's Gulliver's travels (1726).

$3^{6}$ Houlbrook, Prince of tricksters, p. $4^{1}$. 
been a scholar of distinction at Durham University, eventually becoming a doctor of civil law in 1868 . Prior to landing the role of schools inspector in 1874, he had been a schoolmaster, a curate of St Mary's, West Brompton, and then assistant chaplain at Chelsea Hospital. 37 As both a clergyman and a government official, it was easy for his victims to assume 'that a person in his position was truthful and honourable'. ${ }^{8}$ He made the most of this, taking care always to be seen in his clerical coat, and his appearance was described as 'that of a very mild and benevolent cleric'.39 He conducted his correspondence with his clients on the official notepaper of the local government board, Whitehall, which bore the government stamp as an authenticating seal. Receipts he gave his clients for sums deposited stipulated that in the event of Clutterbuck's death, the holder should contact John Jordan, staff officer in charge of accounts at the local government board. These described Jordan as, variously, Clutterbuck's executor, trustee, or legal representative, and gave the transactions a further official imprimatur. $4^{\circ}$ And Clutterbuck constantly reiterated his close relationship with Goschen, claiming that he had a 'personal friendship of [an] intimate character' with the chancellor. $4^{1}$ By these means, he was able to invoke both church and state in support of his scheme.

Moreover, rather than a remote figure, Clutterbuck was known personally or professionally by his victims, and he capitalized on these relations. Many were Bath residents, including fellow clergymen like McCausland and Pace, together with the headmaster of the government school of science and art in Bath, Charles Martin Hodges, medical inspector for the local government board, Dr Francis Henry Blaxall, and Jessie Caroline Turner, a widow. Hodges had known Clutterbuck for ten years, and was 'on very friendly terms' with him; Blaxall had moved to Bath more recently, but relations between the pair's families had moved to 'a very intimate footing'. ${ }^{2}$ Turner was not so close with Clutterbuck, but was very good friends with his wife. These were therefore people Clutterbuck saw informally on a social basis, which enabled him to broach the subject of money very casually, often in chance encounters, in a way that did not seem unusual. For example, Clutterbuck approached Turner as she was leaving the Bath branch of the Wilts and Dorset Bank, and struck up a conversation about her investments. As a result, Turner invited him to her house where they went through her portfolio together, and she agreed to sell out some of her existing investments in order to invest in the Goschen

37 Bath Chronicle, 29 Oct. 1891 , p. 3; Times, 19 Nov. 1892 , p. 9.

$3^{8}$ Western Daily Press, 23 Nov. 1891 , p. 5 .

39 Illustrated London News, 28 Nov. 1891, p. 69o. The Pall Mall Gazette also noted his 'most benevolent countenance': 23 Nov. 1891, p. 1. For artists' impressions, see Pall Mall Gazette, 7 Nov. 1891, p. 7; Devon and Exeter Gazette, 27 Nov. 1891, p. 3 .

$4^{\circ}$ Western Daily Press, 9 Nov. 1891 , p. 3 .

$4^{1}$ Bath Chronicle, 5 Nov. 1891 , p. 2; see also Aberdeen Weekly Journal, 25 Nov. 1891, p. 4; Western Daily Press, 2 Nov. 1891 , p. 8.

$4^{2}$ Bristol Mercury, 7 Nov. 1891, p. 3 . 
loan. 43 Similarly, Clutterbuck first discussed the loan with Hodges in the course of a chance meeting in the streets of Bath. He began by inquiring about the school, of which he was a trustee, then shifted the conversation onto personal finances, asking whether Hodges 'had any money put by which he should like to invest'.44 This resulted in an investment of $£ 700$, and Clutterbuck secured a second instalment from Hodges when the two met just as the reverend was leaving Bath Abbey. In this way, Clutterbuck turned the streets of Bath into the innocuous stage for his performance.

Trust underpinned the expanding social circles that characterized middleclass urban society. A 'new cult of friendship' developed that allowed people to learn and practise 'trustful relations'.45 Friendship was understood as a reciprocal relationship, in which the idea of service was central. The giving and receiving of favours "were opportunities for displaying "acts of friendship"... and obliging the "friend" in further reciprocal exchanges'. $4^{6}$ Clutterbuck framed the investments in this way, as favours to friends. Rather than imploring them to invest, he presented the loan as a special opportunity restricted to a privileged few. For example, he told McCausland that he was allowing him to invest as 'a friend and brother clergyman'. $47 \mathrm{He}$ also informed investors that the amount he was authorized to raise was strictly limited, so the right to place further sums with him was not guaranteed. This enabled him to present such permission, when granted, as an additional favour bestowed on an esteemed friend. When Blaxall asked if he could increase his investment, Clutterbuck wrote him a letter explaining that he would reduce his own share of the loan in order to enable his friend to place a further £6oo. 'I need not say that there is no one to whom I would more willingly do a good turn than yourself, for though our knowledge of each other has not been of very long standing our friendship seems to me to date from long ago.' $4^{8}$ Thus, the personal and the financial were deliberately intermingled: presenting the transaction as a gift strengthened the feelings of reciprocity underpinning trusting relationships. The investments thus brought each party closer together, stimulating feelings of mutual gratitude, respect, and obligation. 49

Clutterbuck was also careful to embed the transactions in the context of family relations. Several times he presented the opportunity to invest as being in return for the thoughtfulness a friend had shown towards his family. He told Pace that he wanted to do him 'a good turn' because of 'the extreme and sustained kindness' Pace's daughter had shown to his own; in a similar

43 Daily News, 22 Oct. 1891 , p. 2.

44 Bath Chronicle, 5 Nov. 1891 , p. 2.

45 Ute Frevert, The moral economy of trust: modern trajectories (London, 2014), pp. 21-2.

$4^{6}$ Naomi Tadmor, Family and friends in eighteenth-century England: household, kinship, and patronage (Cambridge, 2001), p. 213.

47 Western Daily Press, 7 Nov. 1891 , p. 3.

$4^{8}$ Ibid.

49 Finn, The character of credit, ch. 2. 
vein, he said that he was glad to be able to do something for Hodges 'because he had always been so kind to his children' $5^{\circ}$ Stressing his role as the caring father and the value he placed on a friend's contribution to his family's well-being underlined his moral credentials, while domesticating the transactions in this way further intensified the sense of reciprocity Clutterbuck was trying to encourage, increasing the intimacy of the bond and drawing the respective families closer together..$^{1}$ That it deepened trusting relations is suggested by the fact that some friends gave Clutterbuck a great deal of autonomy over their financial affairs. Turner authorized him to make transactions on her behalf at her local bank, while Pace handed over several bonds and shares to Clutterbuck, trusting him to dispose of them on his behalf and reinvest the proceeds. $5^{2}$

Clutterbuck also recruited investors from outside Bath: these were people he encountered in connection with his role as a workhouse schools inspector, including a dozen workhouse masters, and several school mistresses.53 Though these relationships were of a more professional order, and some were probably weaker ties, they included those with whom Clutterbuck had developed close and friendly relations, sometimes over the course of a very long period. William Pearce, master of Dorchester workhouse, had known Clutterbuck ever since the reverend began working for the local government board, and the two were on intimate terms. Clutterbuck's transactions with Pearce were embedded in the same personal and family context as his Bath clients. When Pearce asked him if he could increase his investment in the loan in order to give his sons the best possible start in life, Clutterbuck replied that he was 'disposed to stretch a point' in his favour because Pearce's 'laudable ambition had his cordial sympathy'. When read in court, the letter, which concluded 'with best wishes, ever your sincere friend, J. C. Clutterbuck', provoked 'loud hisses' because of the abuse of friendship it laid out so starkly.54 In this instance, as in others, Clutterbuck insisted upon secrecy-Pearce 'must please remember that what he had told him was absolutely confidential, and must be strictly confined to himself and Mrs. Pearce' - which helped further to bind the families together.55 There is no evidence that Clutterbuck used his position to pressure any of his professional contacts to invest. Though it is of course possible that some felt such pressure, particularly perhaps the school mistresses who invested their small savings with him, no accusations along these lines were made in court or in the press. Indeed, Clutterbuck seems not to have been a rigorous schools inspector, with a reputation for being somewhat lax in checking the proficiency of the

\footnotetext{
50 Western Daily Press, 7 Nov. 1891, p. 3; Bristol Mercury, 7 Nov. 1891, p. 3 .

$5^{1}$ For Victorian middle-class men and family life, see John Tosh, A man's place: masculinity and the middle-class home in Victorian England (New Haven, CT, 1999).

$5^{2}$ Bristol Mercury, 2 Nov. 1891, p. 8; 7 Nov. 1891, p. 3.

53 Pall Mall Gazette, 25 Nov. 1891, p. 6.

54 Bath Chronicle, 5 Nov. 1891, p. 2; Times, 2 Nov. 1891 , p. 12.

55 Times, 2 Nov. 1891, p. 12.
} 
children, so was unlikely to have been seen as an intimidating presence by staff. $5^{6}$ It seems that the ties of friendship and amity were more influential here than those of status or deference. In his dealings with friends and professional contacts alike, trust was an emotional transaction, the financial element just part of a much deeper moral economy. 57

\section{I}

There was more to Clutterbuck's success in inspiring trust than his performance and his manipulation of affective bonds, however. His story was just as important. Recent work in economic sociology has highlighted a basic but critical temporal point about investment: that it is shaped not only by past experience, but is also future-facing. Because the future is unknowable, any act of investment is a leap of faith, characterized above all by uncertainty. Consequently, economic behaviour is underpinned by what Jens Beckert calls 'imagined futures', and decision-making is 'anchored in fictions'. $5^{8}$ The stories people believe are therefore critical to understanding investment behaviour: their 'fictional expectations take a narrative form, and become articulated as stories that tell how the future will look'.59 These stories provide the means of overcoming the anxieties and insecurities generated by the uncertainty of the future, giving people the confidence to act. ${ }^{60}$ Fictional expectations are not formed individually but are 'social phenomena' circulated and shaped by 'powerful actors such as firms, politicians, experts, and the media'. ${ }^{61}$ Sometimes these stories become 'contagious' and affect large numbers of investors, triggering booms and busts. ${ }^{62}$ Certainly, the growth of the financial press in the nineteenth century began to make the mass circulation of influential narratives more possible. Stories also circulated at a more personal level, however, and less powerful actors were able to adopt and exploit narratives for their own ends. The Clutterbuck case shows us how emotionally engaging stories could be used by such actors to cement trust and influence behaviour.

Newspaper editorials recognized Clutterbuck as a storyteller, but accorded his stories low status. His frauds displayed 'no particular cleverness', his

${ }^{5}$ For evidence, see Cormishman, 29 Oct. 1891, p. 5; Evening News, 11 Feb. 1892, p. 2; Hampshire Advertiser, 24 Dec. 1892, p. 3.

57 For more on this idea, see Frevert, Moral economy of trust.

$5^{8}$ Jens Beckert, 'Imagined futures: fictional expectations in the economy', Theory and Society, 42 (2013), pp. 219-4o, at p. 220.

59 Idem, Imagined futures: fictional expectations and capitalist dynamics (Cambridge, MA, 2016), p. 10 .

${ }^{60}$ David Tuckett, Minding the markets: an emotional finance view of financial instability (Houndmills, 2011), p. xvii.

${ }^{61}$ Beckert, Imagined futures, p. 13. For government management of economic narratives, see Jim Tomlinson, Managing the economy, managing the people: narratives of economic life in Britain from Beveridge to Brexit (Oxford, 2017).

${ }^{62}$ Robert J. Shiller, Narrative economics: how stories go viral and drive major economic events (Princeton, NJ, 2019). 
method 'was simply one of audacious lying'. ${ }^{63}$ His tale about local loans was nothing more than a 'cock-and-bull story'. ${ }^{4}$ The outlandishness of his narrative was contrasted with the rigorous realism of novelistic representations of the financial world. ${ }^{6}{ }_{5}$ 'Had any novelist invented a Clutterbuck to decorate his fiction, critics would have said scathing things about the improbability of the man and his misdeeds', wrote The Times ${ }^{66}$ But this downplayed the skill with which Clutterbuck rendered his tall tale eminently plausible. He carefully crafted his story to resonate with his victims, the inventions woven seamlessly together with recognized facts and popular beliefs for maximum plausibility. Chancellor Goschen was indeed reorganizing local finance, a fact that had been widely reported, and choosing to make his fictitious investment a local loan allowed Clutterbuck to draw on this contextual knowledge. ${ }^{67}$ Thus, when Hodges's brother asked for more information about the investment, Clutterbuck wrote to him that it 'originated, as no doubt you have heard, in the desire to consolidate the enormous local indebtedness of the country by the creation of a stock called Local Loans'. ${ }^{68}$ That this was supposedly a government-backed loan also enabled Clutterbuck to present the investment as risk-free. Blaxall was told it was 'as safe as the Bank of England'; in explaining its safety to Hodges, he alluded to the Barings crisis of 1890 , stating that 'Goschen is not the sort of man to dabble in Argentines.'69 Clutterbuck's knowledge of his friends enabled him to inflect the tale in order to maximize its attractiveness to each one. So, he told headmaster Hodges that the loan was designed precisely for men like him 'who, though Government servants, had no chance of superannuation'.$^{\circ}$ Other details were also varied: Pearce, for example, was informed that the investment was for home defence, while he told Pace that it was in government telegraphs. ${ }^{71}$ By assuring his friends that they were investing in government securities rather than, say, speculative foreign loans or mining ventures, Clutterbuck was able to capitalize on what one commentator called 'the provincial prejudice against the Stock Exchange', and made the proposition seem both familiar and safe. $7^{2}$

\footnotetext{
63 Northern Echo, 24 Nov. 1891, p. 2; Bristol Mercury, 23 Nov. 1891, p. 5.

64 Aberdeen Weekly Journal, 25 Nov. 1891 , p. 4.

65 For a recent exploration of representations of finance in realist fiction, see Nancy Henry, Women, literature and finance in Victorian Britain: cultures of investment (Cham, 2018).

66 Times, 23 Nov. 1891 , p. 9. For similar comments, see Spectator, 28 Nov. 1891, p. 756; Citizen, 23 Nov. 1891 , p. 3 .

67 Christine Bellamy, Administering central-local relations, I 87 I-I9I9: the local government board in its fiscal and cultural context (Manchester, 1988), pp. 91-2; Jeremy Wormell, The management of the national debt of the United Kingdom, I900-I932 (London, 2000), pp. 10-11.

68 Bath Chronicle, 12 Nov. 1891 , p. 2.

69 Birmingham Daily Post, 7 Nov. 1891, p. 6.

$7^{\circ}$ Bath Chronicle, 12 Nov. 1891, p. 2.

71 Times, 2 Nov. 1891 , p. 12; Western Daily Press, 7 Nov. 1891 , p. 3.

$7^{2}$ Speaker, 28 Nov. 1891 , p. 632 .
} 
Clutterbuck exploited this prejudice in other ways. In telling his story, he emphasized that Goschen had elected to raise the loan privately through government officials in order to avoid the extortionate fees charged by the likes of Barings and Rothschilds.73 Though the interest paid was very high, 'Rothschild would require much more than that to float such a loan', and Goschen had refused to 'salt Capel Court'.74 Clutterbuck's story thus chimed with the popular belief that governments were 'always being robbed by great financiers, who "float" loans with fabulous profit to themselves', as The Spectator put it. 75 What might have appeared a suspiciously high interest rate could therefore be explained in terms of the huge savings made as a result of bypassing the City of London. ${ }^{6}$ It may have been a cock-and-bull story, but it was expertly told: as The Western Daily Press conceded, Clutterbuck's friends would 'not have been beguiled by a less clever rogue'. 77

Clutterbuck's story was therefore plausible; it also had a compelling emotional resonance for provincial investors living far from metropolitan centres of finance. The financial journalism of this period promised to overcome this distance by providing its readers with the inside tips and confidential gossip that would help them beat the market. $7^{8}$ As Peter Knight argues, this form of journalism purported to provide a 'resolution to the problem of asymmetric information' that characterized the market by 'making outsiders feel like they were insiders'.79 Key to accomplishing this was adopting an informal, firstperson mode of address, and posing as the 'staunch...guide, counsellor, and friend' of readers. ${ }^{80}$ Clutterbuck emulated precisely this appeal, promising to level the playing field for his friends by sharing his inside information, acquired as a result of his government position. The secrecy that he invariably insisted upon was important not only in helping him to avoid detection, but in reinforcing his investors' sense of being favoured with privileged intelligence. As The Globe put it, 'the idea of being admitted into an official secret for one's private advantage is too delightful for the ordinary mind to withstand'. This explained why workhouse masters ('who ought to be up to most forms of trickery'), and government officials ( 'who are presumably men of the world'), could be taken in. ${ }^{81}$ Clutterbuck thus adapted the appeal of a certain brand of financial journalism, but what these newspapers were merely simulating - relaying confidential information to a friend-Clutterbuck could do far more

73 Bath Chronicle, 5 Nov. 1891 , p. 2.

74 Clifton Society, 12 Nov. 1891, p. 14; Bath Chronicle, 12 Nov. 1891 , p. 2.

75 Spectator, 14 Nov. 1891 , pp. $671-2$.

76 Times, 2 Nov. 1891 , p. 12.

77 Western Daily Press, 23 Nov. 1891, p. 5.

$7^{8}$ Dilwyn Porter, "AA trusted guide of the investing public": Harry Marks and the Financial News, 1884-1916', Business History, 28 (1986), pp. 1-17.

79 Peter Knight, 'Reading the market: abstraction, personification and the financial column of Town Topics magazine', Journal of American Studies, 46 (2012), pp. 1055-75, at p. 1068.

8o Financial Answers, 4 Dec. 1895, p. 1; Money-Maker, 11 Nov. 1899 , p. 9.

81 Globe, 23 Nov. 1891 , p. 4 . 
authentically. For his victims, being told that they were being let in on a 'good thing' must have been far more seductive than reading financial gossip in a newspaper which, they might reflect, was available to thousands of others. ${ }^{82}$ And by this method, the bonds between Clutterbuck and his clients deepened: not just friends, they were now co-conspirators.

Nevertheless, it is important to be specific about what Clutterbuck's victims believed, and did not believe. Newspapers in the 1880 os and 189 os were full of extravagant promises about the fortunes that could be made through speculation, and the advertising columns were particularly important here. Boldly addressed to 'PERSONS WISHING TO MAKE MONEY', advertisements in both the London and provincial press assured readers that 'enormous profits are often made by gaining sound information'. ${ }^{8}$ These were placed by enterprising stock and share dealers operating outside of the official exchanges, and therefore not subject to the rules against advertising faced by members. Common to the sales pitch of many of them was the idea that they were modernizing antiquated City practices, using new technologies like the ticker tape and the telephone, and exploiting economies of scale, to offer better terms to members of the public, including reduced rates or even commission-free dealing. ${ }^{8} 4$ Helping to manufacture a popular culture of speculation in late Victorian Britain, these outside dealers and their outsized promises instigated something of a moral panic. Stigmatized as 'bucket shops', their offices were thought to be little better than common gambling dens, with customers betting recklessly on the rise and fall of share prices. ${ }^{8} 5$ Naïve provincial investors were believed to be particularly vulnerable to the temptations they offered ${ }^{86}$ Yet there is no evidence that any of Clutterbuck's investors were patrons of the bucket shop. Rather, they pulled their money from safe investments, or borrowed it in the case of Pearce, to deposit with Clutterbuck. Turner, for example, converted securities in two American railway companies, while Pace cashed in shares in the Army and Navy Cooperative Society. ${ }^{8}$ Nevertheless, the endless dissemination of getrich-quick promises in the press helped to create an environment in which great fortunes were easily imaginable. Despite their warnings about bucket shops, the press was also happy to tell stories about the money that could be

82 Pall Mall Gazette, 23 Nov. 1891 , p. 1

83 Adverts by H. B. Smith and Fred. Spencer, respectively, in Western Daily Press, 3 Mar. 1888 , p. 1 .

84 David C. Itzkowitz, 'Fair enterprise or extravagant speculation: investment, speculation, and gambling in Victorian England', Victorian Studies, 45 (2002), pp. 121-47; Dilwyn Porter, "'Speciousness is the bucketeer's watchword and outrageous effrontery his capital": financial bucket shops in the City of London, c. 1880-1939', in John Benson and Laura Ugolini, eds., Cultures of selling: perspectives on consumption and society since I 7oo (Aldershot, 2006), pp. 103-25.

${ }_{5}$ James Taylor, 'Inside and outside the London Stock Exchange: stockbrokers and speculation in late Victorian Britain’, Enterprise E Society, forthcoming (online).

86 Cosmopolitan Financier, Nov. 1907, pp. 194-5; Roland Belfort, 'Stockbrokers and their clients', World's Work, July 19o8, pp. 181-6.

87 Bristol Mercury, 2 Nov. 1891 , p. 8; Bath Chronicle, 12 Nov. 1891 , p. 2. 
won, like the Philadelphian tram conductor who was made redundant without a cent to his name and with a family to support, but, starting with a borrowed 10 dollars, invested so successfully with outside brokers that he eventually made $\$ 40$, ooo. ${ }^{88}$ So when Clutterbuck promised his friends similarly wonderful returns, but with government-backed safety, it did not seem so far-fetched. Indeed, there is the suggestion that Clutterbuck played upon the sense of envy generated by the late Victorian normalization of big profits. When persuading Hodges to invest, he pulled out a book and showed him a list of names with figures next to them, highlighting one name in particular and the large sums of interest this person had been earning quarterly. Hodges knew several of the names by reputation, and seeing their wealth effortlessly accumulating in the pages of Clutterbuck's pocketbook seems to have helped him to contemplate investing himself. ${ }^{89}$

The case thus complicates how we understand investors, suggesting that it not as straightforward as it seems to categorize them according to attitude to risk, with conservative investors prioritizing safety, and speculative ones willing to take a gamble. Bath was widely regarded as the home of the archetypally cautious investor - the 'City of 3 per cents' - and newspapers thought it incredible that Clutterbuck had managed to persuade its residents to subscribe to his 'private and confidential "Goschens" at 10 per cent' $9^{\circ}$ Yet he had not turned them into reckless plungers, despite the press's eagerness to view the case as symptomatic of the 'atmosphere of gambling' that was now sadly prevalent in society..$^{1}$ Rather, he was profiting from a wider climate in which ordinary investors' 'imagined futures' could easily include big returns, earned safely, given access to the right information. His friends believed that they were behaving entirely sensibly.

\section{I I}

So far, we have focused on the trust that was placed in Clutterbuck, but we can also explore the trust Clutterbuck placed in others. His friends may have resisted the lure of the bucket shop brokers, but the same could not be said for Clutterbuck himself. The criminal investigation quickly uncovered why he had such a thirst for capital, given he enjoyed a relatively substantial salary of $£ 6$ oo, plus $£_{2} 5^{\circ}$ travel expenses. $9^{2}$ In September 1887 , he had established a second household with a woman in Plymouth, and soon found his finances stretched.93 He faced the additional problem that, due to his modest salary when he married, he had made an arrangement with his mother-in-law

88 Dover Express, 23 Mar. 1888, p. 6.

89 Western Daily Press, 2 Nov. 1891, p. 8.

9o Pall Mall Gazette, 1 Dec. 1891, p. 2; Weston-Super-Mare Gazette, 25 Nov. 1891, p. 2.

$9^{1}$ Globe, 23 Nov. 1891 , p. 4 .

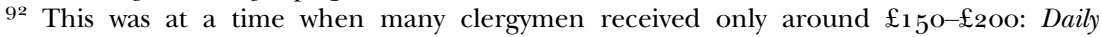
Telegraph, 23 Nov. 1891 , p. 5 .

93 Western Daily Press, 23 Nov. 1891, p. 7. 
whereby she vested most of her fortune in her daughter, on the understanding that, when he landed a better-paying job, his salary would be paid into his wife's account.94 Looking for ways to boost both his income and his financial autonomy, in December he came across the advertisements of Darnley Roland Darnley, one of the new generation of outside brokers, who was seeking capital to fund his business. Darnley promised Clutterbuck 20 per cent interest on any money he could lend him, plus 5 per cent commission. Not having any spare cash to invest himself, Clutterbuck approached McCausland with his story about Goschen's loan. The $£_{5}$ oo which McCausland entrusted to Clutterbuck went straight to Darnley.95 Though the reverend's relationship with his Plymouth mistress ended soon after, he set up another establishment with a young woman named Ellen White in Exmouth the following year, so his need for money continued. $9^{6}$ Over the course of eighteen months, he funded Darnley's brokerage to the tune of $£ 7,040$ : as soon as he received money from one of his investors, he passed it on to the broker. Darnley regularly paid Clutterbuck interest on the loan, which the reverend used in order to pay interest to his investors. Borrowing money at a lower rate than he was lending it for seemed an infallible system for making money. 97

An even more lucrative opportunity presented itself in December 1888 when Clutterbuck came across another advertisement: 'INCOMES INCREASED. - By dealings in Stocks and Shares by a private dealer, 5 o per cent. guaranteed on investments, regularly paid during the past two years. ${ }^{98}$ The private dealer in question was Edwin Bliss, another outside broker, who assured Clutterbuck that clients who opened a discretionary account with him, allowing him to invest their money as he saw fit, could in fact make profits of 100 per cent.99 Impressed, Clutterbuck began channelling funds to Bliss as well as to Darnley. But the flaw in Clutterbuck's schemes first suggested itself in the autumn of 1889 when both brokers became insolvent, their speculations

94 When he married, he had been 'a poor struggling schoolmaster': Devon and Exeter Gazette, 25 Feb. 1892 , p. 8. For more on how marriage settlements could preserve married women's financial independence, see Amy Louise Erickson, 'Common law versus common practice: the use of marriage settlements in early modern England', Economic History Review, 43 (1990), pp. 21-39.

95 Western Daily Press, 9 Nov. 1891, p. 3; Daily News, 9 Nov. 1891, p. 7; Bath Chronicle, 12 Nov. 1891 , p. 2.

$9^{6}$ Times, 14 July 1892 , p. 14. The prosecution's allegations about Clutterbuck's mistresses were not evidenced, but further details corroborating these allegations came out during the subsequent bankruptcy proceedings, though Clutterbuck insisted that his relations with White were innocent, and that she merely acted as his secretary: Western Gazette, 15 July 1892 , p. 8.

97 Bath Chronicle, 26 Nov. 1891 , p. 7.

$9^{8}$ Standard, 6 Dec. 1888, p. 8. Versions of this advert had appeared in a variety of London and provincial papers from September 1887 .

99 The Financial Times began printing warnings against Bliss around this time; Clutterbuck was evidently not a reader: Financial Times, 11 Dec. 1888, p. 2; 29 Apr. 1889, p. 1; 23 May 1889 , p. 2; 26 July 1889 , p. 1. 
having failed. Facing massive losses, Clutterbuck doubled down. When Edward Morgan, a young mining engineer, took over Darnley's old brokerage, Clutterbuck financed it to the tune of $£ 8$, ooo. He also placed $£_{5}, 6$ oo with Robert James Laidlaw, an accountant who was looking over Bliss's affairs, and who sometimes dabbled in the markets on behalf of friends. ${ }^{100}$ When these yielded disappointing results, he even responded to a newspaper advertisement promising 'an infallible system of winning money by backing horses on the turf', stumping up $£_{2}, 65^{\mathrm{o}}$, but receiving back only $£_{90} .^{101}$

Thus, Clutterbuck both fooled and was fooled. 'The same promises of extravagant interest which he had made to some persons, he allowed others to make to him', The Daily News observed. ${ }^{102}$ Indeed, The Financial Times thought that Clutterbuck had shown himself even more credulous than his friends, being misled 'by statements still more absurd and improbable even than his own'. ${ }^{103}$ Darnley and Bliss convinced Clutterbuck that securing very large profits with very low risk was possible, to that extent that he did not believe that he was doing anything dangerous. When quizzed during bankruptcy proceedings about the brokers he speculated with, Clutterbuck demurred: 'you can hardly call it speculated with...I deposited money at guaranteed interest.' ${ }^{104} \mathrm{He}$ internalized their stories about low risk and high profits and regurgitated them, in amended form, to his victims. Naturally, Clutterbuck did not believe the stories he told his friends about Goschen's loan, but he very much did believe that, through his outside brokers, he would be able to make the profits he promised them: this is why he attempted to plead not guilty to the intent to defraud.

Though Clutterbuck first encountered his brokers through print advertisements, the trust he came to place in them was cultivated through face-to-face relations, as it was with his own friends. He did not simply send Darnley a cheque on the strength of the initial advert; rather, he went to meet the broker at his City office, and was impressed by the sums he said he could make by speculation. Subsequently, he went to see Darnley often, preferring to hand over the money he was lending him, which was often in notes, in person. ${ }^{105}$ After he responded to Bliss's advertisement, Bliss came to see him at the local government board to talk about the profits he could make for him. On the strength of this, Clutterbuck invested an exploratory £25, but soon increased his stake. As with Darnley, Clutterbuck met with Bliss when in London, usually at the Caledonian Hotel, near the Adelphi Theatre. ${ }^{106}$ The

100 Bath Chronicle, 26 Nov. 1891, p. 7.

101 Western Daily Press, 23 Nov. 1891, p. 7.

102 Daily News, 23 Nov. 1891 , p. 5 .

103 Financial Times, 24 Nov. 1891, p. 2.

104 Devon and Exeter Gazette, 25 Feb. 1892 , p. 8.

105 Clifton Society, 12 Nov. 1891, p. 14.

106 Bath Chronicle, 12 Nov. 1891, p. 2. He also met with Laidlaw in the same hotel: Times, 9 Nov. 1891 , p. 7 . 
pair seem to have become close: when he was arrested, he was at Bliss's Chelsea home with White, his mistress. ${ }^{107}$ The implicit trust Clutterbuck's friends placed in him mirrored the unconditional trust he placed in his brokers. He did not ask Darnley for security for the loan, nor did he require details of exactly what he would do with the money, satisfied that Darnley would be able to make him the promised profits. ${ }^{108}$ Likewise, he trusted Bliss, and later Laidlaw, to speculate as they saw fit, giving them complete discretion in the choice of investments. ${ }^{109}$ His trust was such that his investments became deeply imbricated with his domestic arrangements: he encouraged White to invest with his brokers, and managed these investments on her behalf. ${ }^{10} \mathrm{He}$ also persuaded his wife to invest; the losses she sustained ultimately meant that she and her daughters had to move in with her son, a young solicitor in London. ${ }^{111}$

The brokers spun Clutterbuck stories about the profits they could make, and any doubts Clutterbuck may have had about them were assuaged by the monthly interest they paid him. Backed by cash, their promises seemed all the more reliable. The brokers knew this: whenever Bliss's speculations went badly, he paid Clutterbuck the interest regardless, hoping to make up the losses on the next account. ${ }^{12}$ Clutterbuck also understood the power of these payments to sustain trust: he paid his investors their interest regularly if they requested it, or gave them detailed statements showing their compound interest accumulating. ${ }^{13}$ When his losses mounted, he used part of the capital he was receiving from some of his friends to cover the interest payments due to other friends rather than risk breaking the spell. ${ }^{14}$ When Darnley went bust, he continued to pay his wife the interest on her investment, 'fearing that the shock of the knowledge that the money had been lost would impair her health'. ${ }^{115}$ It is therefore ironic that he allowed himself to be taken in by the same method.

More striking still is the durability of Clutterbuck's trust. When Darnley announced that he had lost Clutterbuck's entire capital, Clutterbuck stopped investing with him, but it did not sour relations between the pair, for when Darnley started out in business again in June 1890 with $£_{1}$, ooo borrowed from the Reliance Insurance Company, Clutterbuck acted as one of the sureties for the loan. ${ }^{16}$ Remarkably, the bulk of the money he placed with Bliss - at least $£_{1} 5$, OOO - he invested after the broker's insolvency in late 1889 , based on Bliss's

${ }^{107}$ Bath Chronicle, 16 June 1892 , p. 5 .

108 Daily News, 9 Nov. 1891, p. 7.

109 Bath Chronicle, 12 Nov. 1891 , p. 2. Outside brokers often encouraged customers to open discretionary accounts: Peter Knight, Reading the market: genres of financial capitalism in gilded age America (Baltimore, MD, 2016), pp. 64-9.

110 Devon and Exeter Gazette, 25 Feb. 1892 , p. 8.

111 Pall Mall Gazette, 25 Nov. 1891, p. 6; Clifton Society, 26 Nov. 1891, p. 9.

112 Bath Chronicle, 12 Nov. 1891 , p. 2.

113 Bristol Mercury, 7 Nov. 1891, p. 3; Western Daily Press, 7 Nov. 1891, p. 3 .

114 Bath Chronicle, 25 Feb. 1892 , p. 8.

115 Devon and Exeter Gazette, 25 Feb. 1892 , p. 8.

116 Bath Chronicle, 12 Nov. 1891 , p. 2. 
insistence that he could make back the money he had lost. ${ }^{117}$ The money kept coming even after Bliss experienced further losses as a result of the Barings crisis the following year. Indeed, Clutterbuck continued trusting Bliss until the end: days before proceedings against him began, he went to Bliss with a further $£_{1}$, ooo for him, but Bliss, perhaps realizing that his own behaviour might shortly be scrutinized in court, told him 'he did not think it desirable to speculate with it', and returned the money. ${ }^{118}$ Clutterbuck's actions here may have been the final roll of the dice of the overcommitted gambler, but it was belief as much as desperation that drove him, for Clutterbuck's trust survived even his trial and conviction. During bankruptcy proceedings, he attributed his insolvency not to the unreliable promises of the brokers, but to the criminal proceedings which had been instituted against him. Unrepentant, he maintained that he 'had been guilty of nothing more culpable than a want of foresight and discretion'. ${ }^{19} \mathrm{He}$ even boasted that he would eventually be able to pay off all his debts, plus interest, thanks to a sinking fund established by Morgan - the man who had taken over Darnley's brokerage - and financed by his speculations, a plan which, unsurprisingly, came to nothing. ${ }^{120}$

Viewing Clutterbuck as the middle link in a chain of deception reveals uncanny parallels in the strategies used for generating and maintaining trust throughout this chain. Originating in an unreliable story, nurtured by friendship, and sustained by the imagination, the trust Clutterbuck placed in his brokers looked remarkably similar to the trust he inspired in his investors. And just as he trusted till the end, so none of his friends chose to cash out of their 'local loans' till it was too late. ${ }^{121}$ Their trust cost them dear; for the brokers, on the other hand, there was no comeuppance, and they were even spared the ordeal of a cross-examination in the criminal trial due to Clutterbuck's guilty plea. ${ }^{122}$ Clutterbuck himself paid a heavy price, however. Still bullish in the court of bankruptcy, his spirits faded as his prison sentence wore on. By August 1892, his health had deteriorated, and he was given lighter labour to perform. But by November, his constitution had completely given way, and he was admitted to the prison infirmary. Though offered 'fish, fowl, jellies and champagne', he refused to eat, and stopped speaking to anyone, including the doctor. The stories had run out. He died on 18 November, nearly a year to the day after his trial, as a result of heart failure.

\footnotetext{
117 Clifton Society, 12 Nov. 1891, p. 14.

118 Western Times, 16 June 1892 , p. 4 .

119 Times, 25 Feb. 1892 , p. 14.

120 Western Gazette, 26 Feb. 1892 , p. 8.

121 The sole exception was Jessie Turner, prompted not by any change of heart on her part, but by her brother-in-law's discovery of her investments. Not having met Clutterbuck, nor having been encouraged to dream about the returns the reverend could make for him, he did not trust him and successfully insisted upon an immediate refund.

122 Clifton Society, 26 Nov. 1891 , p. 9 .
} 
The press suggested that he died of 'a broken heart'. ${ }^{123}$ Alternatively, we could speculate it was the shattering of the fictional expectations that had driven him for so long.

\section{V}

The growing complexity of the financial markets in the later nineteenth century left many investors feeling bewildered. Newspapers, circulars, and manuals promised to demystify investment but often confused more than they clarified. As Sir Henry Burdett, editor of the London Stock Exchange's Official intelligence, admitted in the 1890 s, it was useless for those with 'no head for figures' to try to make sense of the market data he so assiduously compiled every year, and that 'for practical purposes an investor must depend largely upon his broker when selecting his investments'. ${ }^{124}$ Indeed, stockbrokers, together with bankers and solicitors who also advised on investments, were the human 'access points' of an increasingly abstract and deterritorialized stock market, playing a critical role in facilitating participation. ${ }^{125}$ Though they could appeal to a growing sense of professional expertise by the later nineteenth century, these formal intermediaries could also seem remote and unapproachable figures, especially to small investors. ${ }^{126}$ Moreover, scandals involving bad behaviour by such intermediaries always attracted significant press attention, which underlined the precarity of dealing with a stranger. ${ }^{127}$ The Clutterbuck case demonstrates how readily investors could be persuaded to trust someone in their immediate social circle, and how robust such trust was. As a consequence, understanding everyday financial behaviour involves taking into account not only the activities of formal market intermediaries like stockbrokers, but also informal, self-appointed ones like Clutterbuck. The argument is not that trusting a friend would always end in catastrophe, but that when it did, such disasters shine a light on Victorian investors' willingness to privilege affective bonds when it came to the stock market. Friendship and finance were tightly interwoven.

Abuses of this kind of trust, as in the case of Clutterbuck, were regarded as shocking, and in the process of 'sense-making' that followed such episodes, press commentators sought to fashion narratives explaining what had gone wrong and how to prevent a repetition. ${ }^{128}$ But the results should not be

123 Bath Chronicle, 1 Dec. 1892 , p. 7.

124 Burdett's official intelligence for 1898 (London, 1898), p. 7 .

125 The term is coined in Giddens, Consequences of modernity, pp. $8_{3}-8$.

126 Taylor, 'Inside and outside', p. 20.

127 For examples in one local paper in the year Clutterbuck began soliciting investments, see Bath Chronicle, 13 Jan. 1887 , p. 2; 14 Apr. 1887 , p. 5 ; 16 June 1887, p. 5; 14 July 1887, p. 2; 13 Oct. 1887 , p. 6 ; 17 Nov. 1887 , p. 5 ; 24 Nov. 1887 , p. 6 ; 15 Dec. 1887 , p. 5 .

${ }^{128}$ For a useful discussion of this process, see Per Hansen, 'Making sense of financial crisis and scandal: a Danish bank failure in the first era of finance capitalism', Enterprise $\mathcal{E}$ Society, 13 (2012), pp. 672-706. 
taken at face value. By presenting the episode as a morality tale, complete with an absurd villain and idiotic victims, the press obscured its significance. Such obfuscation performed important cultural work, rendering the whole episode more comprehensible and less disturbing. Commentators were attempting to shore up the differences between safe investment and risky speculation, real security and fantastic fraud-most fundamentally, between fact and fictionupon which the market depended. These differences had to be seen as obvious for confidence in the market to be maintained. Such interpretations flattered and reassured readers: able to recognize Clutterbuck's story as nonsense, they were unlikely to fall for such a swindle themselves. Unpicking these tales allows us instead to highlight the power of the plausible man - or woman - to disrupt these categories. ${ }^{129}$ Clutterbuck spun his story in an atmosphere already thick with narratives. Advertisements, prospectuses, journalists, brokers, not to mention novelists and playwrights, all circulated competing stories about the market, yet hindsight alone provided certain means of distinguishing the trustworthy from the unreliable. Despite attempts to defuse their troubling implications, cases like Clutterbuck's drew attention to finance's inherent fictionality, suggesting that when investors ventured into the market, all they had were stories.

129 Houlbrook, Prince of tricksters, pp. 19-20. Though women's ability to act as formal market intermediaries was limited in these years, there was far more scope for them to perform this role informally, deploying the same repertoire of strategies available to men. For a colourful example, see the case of Marie Josephine Leslie: Old Bailey Proceedings Online (www.oldbaileyonline.org, version 8.o), July 19o7, trial of LESLIE, Marie Josephine (39) (t19070722-52). 